\title{
EFFECT OF VIRUS ANTIBODY ON INFECTION OF MOUSE BRAIN BY MOUNT ELGON BAT VIRUS
}

\author{
J. R. PATEL* \\ Department of Microbiology, University of Reading, \\ London Road, Reading RGI $5 A Q$
}

\begin{abstract}
SUMmary. Intranasal inoculation of mice aged 1-6 days with Mount Elgon bat virus produced an acute brain infection and death of all the mice at 5-7 days after inoculation. Virus multiplied in the olfactory bulbs and spread to the midbrain and then hindbrain, reaching titres of $10^{9}-10^{10}$ plaque forming units/g of wet tissue. Fatal disease was prevented by administration of virus antibody after infection, which was then restricted to the olfactory bulbs. Antibody was ineffective when infection was established in the midbrain; it reduced infectivity by about $99 \%$ in olfactory bulbs but by only a small fraction in midbrain and hindbrain. The findings may reflect differences in virus maturation and spread, and the accessibility of virus antibody to the olfactory bulbs, midbrain and hindbrain.
\end{abstract}

\section{INTRODUCTION}

There have been many studies of viral invasion, replication, and the role of the host defences, particularly the immune responses, in the pathogenesis of primary viral infections of the central nervous system (CNS) (Hotchin, 1967; Albrecht, 1968; Johnson and Mims, 1968; Nathanson and Cole, 1970). Mount Elgon bat virus (MEBV) is an antigenically distinct rhabdovirus which was isolated, in suckling-mouse brain, from the salivary glands of a bat, Rhinolophus hildebrandti eloquens (Metselaar et al., 1969). The pathogenesis of the virus infection was subsequently studied in mice (Murphy et al., 1970; Patel, 1979a and $b$ ). Virus administered intranasally or intracerebrally killed suckling mice readily but older mice became progressively resistant (Patel, $1979 a$ and $b$ ); this age-related resistance was ascribed to maturation of host immune responses. In sucklings up to 13 days of age, virus administered intranasally invaded the olfactory bulbs via the olfactory nerve and grew to high titre in olfactory bulbs, midbrain and hindbrain, killing the mice (Patel, 1979a). Older sucklings were resistant to intranasal infection yet virus invaded and persisted in the olfactory bulbs until the appearance of an immune response (Patel, 1979a). In the experiments reported here, the effect of virus antibody administered after the intranasal infection of mice aged 1 day or 4-6 days was studied.

\section{MATERIALS AND METHODS}

Virus. A sixth passage of MEBV in suckling-mouse brain was prepared and titrated (Patel, 1978). The titre of a $10 \%(\mathrm{w} / \mathrm{v})$ stock suspension stored at $-70^{\circ} \mathrm{C}$ was $8.4 \log _{10}$ plaque forming units (pfu) $/ \mathrm{ml}$.

Virus antiserum. Adult female mice, strain LACA, that survived intracerebral inoculation of $10^{6} \mathrm{pfu}$ (Patel, 1979b) were given an intraperitoneal injection of $1 \times 10^{6}$ sarcoma-37 cells suspended in phosphate-buffered saline, $p \mathrm{H} 7 \cdot 3$ (PBSA, Oxoid) 2 weeks after the virus inoculation; ascitic fluid was collected 1 week later. Normal ascitic fluid was prepared in mice by intracerebral injection of $0 \cdot 1 \mathrm{ml}$ of a $10 \%(\mathrm{w} / \mathrm{v})$ suspension of normal suckling-mouse brain.

Received 10 Mar. 1981; revised version accepted 2 Jun. 1981.

* Present address: Dept. of Communicable Diseases, Clinical Research Centre, Northwick Park, Watford Road, Harrow, Middlesex HAl 3UJ. 
The virus-neutralising titre of the pooled immune ascitic fluid was 20480 , but activity was not detected in normal ascitic fluid in a plaque-count-reduction assay in chick cells (Patel, 1978).

Mice. Outbred category-4 LACA mice were used (Patel, 1979a). Sex-related differences in susceptibility to the virus had not been observed (Patel, 1979a) and equal numbers of male and female mice were used in all experiments.

Experimental design. Groups of 16 mice aged 1 day and 4-6 days were inoculated intranasally with $10^{6} \mathrm{pfu}$ of virus and given immune ascitic fluid intraperitoneally $(0 \cdot 1 \mathrm{ml} / \mathrm{mouse})$ 30,52 or $72 \mathrm{~h}$ later. Control groups were given normal ascitic fluid at $30 \mathrm{~h}$. The survival time in each group was recorded during 50 days. In each group, two male and two female mice were killed before and after administration of immune or normal ascitic fluid and the infectivity in pooled olfactory bulbs, mid-brain and hindbrain was determined by plaque count in chick cells (Patel, 1978, 1979a). Other tissues were not assayed because they did not yield virus except for nasal mucosa, which became infected after the virus had multiplied in the olfactory bulbs (Patel, 1979a). The serum of normal sucklings aged 1 day or 4-6 days was tested for virus-neutralising antibody daily for 7 days after intraperitoneal injection of the immune ascitic fluid; titres were 1024-5160. Tests were not done for virus antibody in brain of these sucklings, neither were tests done to determine whether the mice that were protected by virus antibody manifested an anamnestic antibody response.

\section{RESULTS}

\section{Infection in mice aged 1 day}

In the control group, virus was first detectable in the olfactory bulbs $24 \mathrm{~h}$ after infection (figure, a); by $48 \mathrm{~h}$ the olfactory bulbs contained $5.5 \log _{10} \mathrm{pfu} / \mathrm{g}$ of wet tissue and the midbrain $4.0 \log _{10} / \mathrm{g}$ of wet tissue; by $72 \mathrm{~h}$ the virus had spread to the hindbrain (figure, a). Mice began to die at $96 \mathrm{~h}$ when the brain contained $9-10 \log _{10} \mathrm{pfu} / \mathrm{g}$ of wet tissue (figure, a). Virus-neutralising antibody was not detected in pooled serum from four control mice tested daily for 4 days. Infected 1-day-old mice given virus antibody $30 \mathrm{~h}$ after infection yielded virus from the olfactory bulbs at $48 \mathrm{~h}$ after infection but this declined to less than $2.5 \log _{10} \mathrm{pfu} / \mathrm{g}$ (figure, b); all the mice in this group survived infection (see the table). Although virus antibody given $52 \mathrm{~h}$ after infection did not prevent fatal disease (see the table), it considerably reduced the amount of virus recovered from olfactory bulbs; it was less effective in reducing virus in the midbrain and hindbrain (figure, c).

\section{Infection in mice aged 4-6 days}

Virus infection of control sucklings resulted in death of the mice by 7 days. Virus was first recovered from the olfactory bulbs at $48 \mathrm{~h}$, followed by midbrain at $72 \mathrm{~h}$ after infection and hindbrain a day later (figure, d); by $120 \mathrm{~h}$, virus titres of $8-9 \log _{10} / \mathrm{g}$ of wet tissue were found in olfactory bulbs, midbrain and hindbrain of these mice. If they were given virus antibody $30-52$ $\mathrm{h}$ after infection, more than $90 \%$ of these sucklings survived and transient virus growth was

\section{TABLE}

The protection conferred by virus antibody on mice aged I day or 4-6 days infected intranasally with Mount Elgon bat virus

\begin{tabular}{c|cc}
\hline $\begin{array}{c}\text { Time of antibody } \\
\text { administration (h after } \\
\text { infection) }\end{array}$ & \multicolumn{2}{c}{$\begin{array}{c}\text { Number surviving/number } \\
\text { inoculated at age of }\end{array}$} \\
\cline { 2 - 3 } & 1 day & $4-6$ days \\
\hline 30 & $16 / 16$ & $16 / 16$ \\
52 & $0 / 16$ & $15 / 16$ \\
76 & $0 / 16$ & $0 / 16$ \\
\hline
\end{tabular}

* Observation period was 50 days; all control mice died by 5-7 days. 

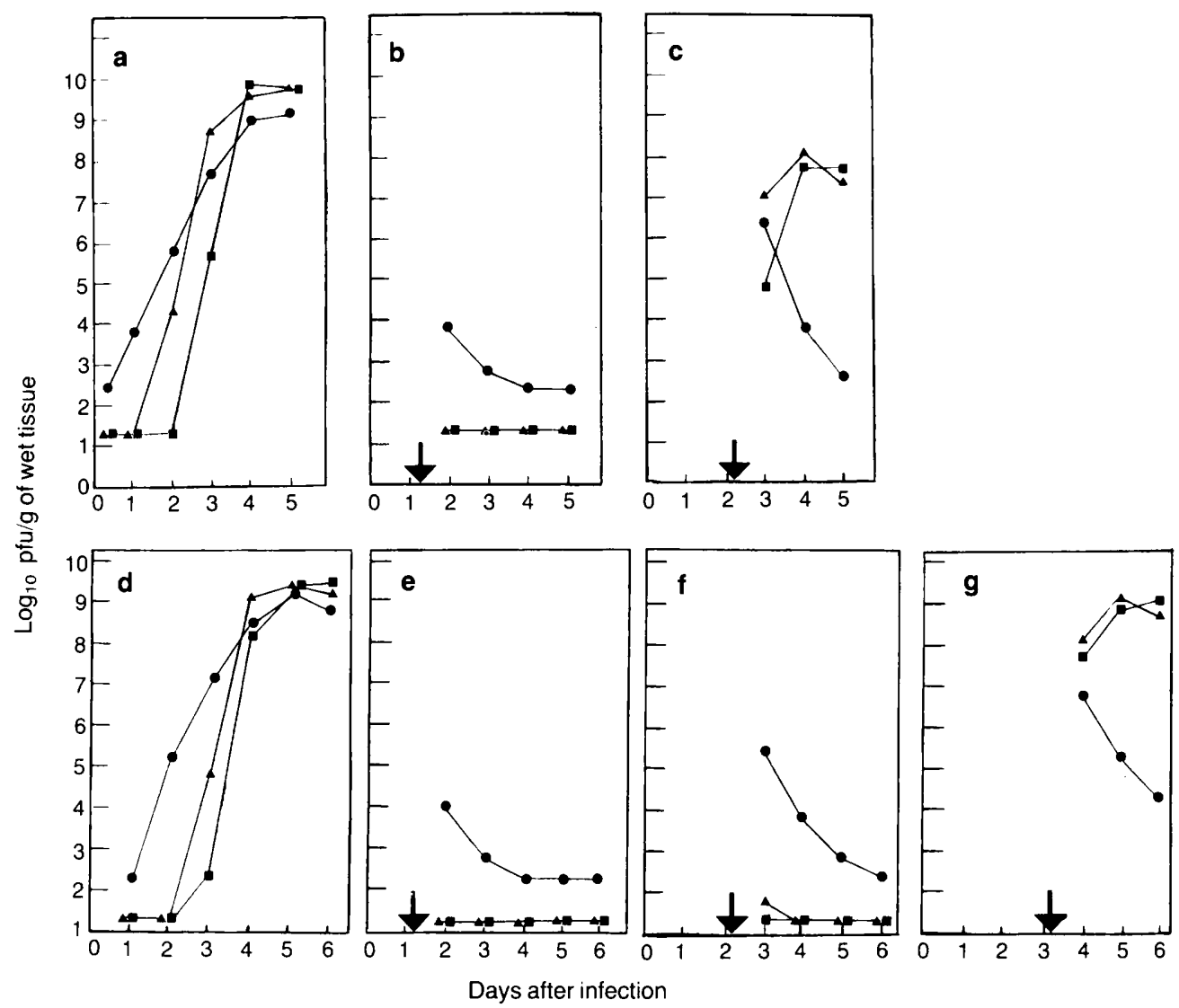

Figure.-Effect of virus antibody on titre of Mount Elgon bat virus in brain; 1-day-old (a-c) and 4-6-day-old mice $(\mathrm{d}-\mathrm{g})$ were infected intranasally with $10^{6} \mathrm{pfu}$ followed by an intraperitoneal injection of immune ascitic fluid $(0.1 \mathrm{ml} /$ mouse) $30(\mathrm{~b}$ and e) $52(\mathrm{c}$ and $\mathrm{f}$ ) and $76 \mathrm{~h}(\mathrm{~g})$ later (arrows). In each group two male and two female mice were killed at intervals and $10 \%(\mathrm{w} / \mathrm{v})$ suspensions of the olfactory bulbs $(\bullet)$, midbrain $(\Delta)$ and hindbrain $(\boldsymbol{\square})$ in ice-cold gelatine $\left(0.5^{\circ} \%, \mathrm{w} / \mathrm{v}\right)$ in PBSA were titrated for infectivity after pooling corresponding tissues. Control groups (a and d) were given normal ascites fluid $30 \mathrm{~h}$ after virus inoculation.

restricted to the olfactory bulbs (see the table and the figure, e and $\mathrm{f}$ ), whereas those given virus antibody $76 \mathrm{~h}$ after infection died with considerable virus growth in the midbrain and hindbrain (see the table and figure, g).

\section{Discussion}

Previous reports have shown that the brain is the target organ for MEBV in mice (Metselaar et al., 1969; Murphy et al., 1970; Patel, 1979 $a$ and $b$ ). This and the lack of viraemia (Patel, 1979a and $b$ ) closely parallels infection of experimental hosts by rabies and related viruses (Murphy, 1977). It has been established, in weanling and adult mice, that the immune response was responsible for their recovery from low-grade, midbrain and hind-brain infection (Patel, 1979a and $b$ ). The immune response was shown to be important in the recovery of a proportion of mice from an established brain infection by rabies (Lodmell et al., 1969) and several other neurotropic viruses (Nathanson and Cole, 1970). The present experiment suggests differences in the protective effect of virus antibody at different sites in the brain. Whereas control suckling mice died from MEBV encephalitis before forming detectable virus-neutralising antibody (Patel, $1979 a$ and $b$ ), the present experiment shows that virus antibody given intraperitoneally could 
prevent the fatal disease even when virus had grown in the olfactory bulbs. The antibody appeared to prevent infection in the olfactory bulbs from extending into the midbrain and thence to the hindbrain but it was apparently ineffective after infection had been established in the midbrain. In the latter groups of mice, the antibody reduced infectivity by $99 \%$ in olfactory bulbs but by only a small fraction in midbrain and hindbrain. Thus, passively given virus antibody may have spread to the olfactory bulbs but not to the midbrain and hindbrain. The rate and extent of virus growth in the three areas of the brain were similar and could not account for the differences observed.

Although the mechanism of virus neutralisation is not clearly understood (Della-Porta and Westaway, 1978), if antibody can limit or arrest an existing CNS infection then the spread of virus is likely to be through extracellular space (Liu et al., 1959; Albrecht, 1968; Nathanson and Cole, 1970). MEBV (Murphy et al., 1970), rabies (Miyamoto and Matsumoto, 1967) and Klamath viruses (Murphy et al., 1972) form cytoplasmic inclusions in mouse brain; these are presumed sites of virus maturation, differing perhaps from those of other rhabdoviruses that mature at the plasma membrane (Knudson, 1973). This raises the question of whether MEBV matures predominantly at the plasma membrane in olfactory-bulb neurones (Patel, 1979a). Studies of this, and the availability of antibody in the brain (Lodmell et al., 1969) may give an insight into the pathogenesis of infection with MEBV and other neurotropic viruses such as rabies.

\section{REFERENCES}

AlbreCht, P. 1968. Pathogenesis of neurotropic arbovirus infections. Curr. Top. Microbiol. Immun., 43, 44.

Della-Porta, A. J. and Westaway, E. G. 1978. A multi-hit model for the neutralization of animal viruses. J. gen. Virol., 38, 1.

HотснIN, J. 1967. Immune and autoimmune reactions in the pathogenesis of slow virus disease. Curr. Top. Microbiol. Immun., 40, 33.

Johnson, R. T. AND Mims, C. A. 1968. Pathogenesis of viral infections of the nervous system. New Engl. J. Med., 278, 23.

KNudSON, D. L. 1973. Rhabdoviruses. J. gen. Virol., 20, suppl., 105.

Liu, O. C., Carter, J. E., Sanders, B. E., Smith, E. C., Hampil, B. 1959. A study on serotherapy of poliomyelitis in rhesus monkeys. Br. J. exp. Path., 40, 133.

Lodmell, D. L., Bell, J. F., Moore, G. J. and Raymond, G. H. 1969. Comparative study of abortive and nonabortive rabies in mice. J. inf. Dis., 119, 569.

Metselaar, D., Williams, M. C., Simpson, D. I. H., West, R. and Mutere, F. A. 1969. Mount Elgon bat virus: a hitherto undescribed virus from Rhinolophus hildebrandtii eloquens. Arch. ges. Virusforsch., 26, 183.

Miyamoto, K. AND Matsumoto, S. 1967. Comparative studies between pathogenesis of street and fixed rabies virus. J. exp. Med., 125, 447.

Murphy, F. A. 1977. Rabies pathogenesis. Brief review. Archs Virol., 54, 279.

MurPhy, F. A., Johnson, H. N., HARRISON, A. K., AND SHOPE, R. E. 1972 . Ultrastructural characterization of a new member of the rhabdovirus group-Klamath virus. Arch. Ges. Virusforsch., 37, 323.

Murphy, F. A., Shope, R. E., Metselaar, D. and Simpson, D. I. H. 1970. Characterization of Mount Elgon bat virus, a new member of the rhabdovirus group. Virology, 40, 288.

Nathanson, N., AND Cole, G. A. 1970. Immunosuppression and experimental virus infection of the nervous system. Adv. Virus Res. 16, 397.

PATEL, J. R. 1978. A plaque assay for Mount Elgon bat virus based on intrinsic interference. $J$. gen. Virol., 40, 659.

PATEL, J. R. 1979a. Invasion of mouse brain by Mount Elgon bat virus. J. gen. Virol., 44, 587.

PATEL, J. R. 1979b. The pathogenesis of infection in mouse brain by Mount Elgon bat virus. $J$. gen. Virol., 45, 591. 